\title{
Determination of the Backfilling Time for the Zinc and Lead Ore Deposits with Application of the BackfillCAD Model
}

\author{
Krzysztof Skrzypkowski
}

Citation: Skrzypkowski, K.

Determination of the Backfilling Time for the Zinc and Lead Ore Deposits with Application of the BackfillCAD Model. Energies 2021, 14, 3186. https://doi.org/10.3390/en14113186

Academic Editor: Maxim Tyulenev

Received: 5 May 2021

Accepted: 27 May 2021

Published: 29 May 2021

Publisher's Note: MDPI stays neutral with regard to jurisdictional claims in published maps and institutional affiliations.

Copyright: (C) 2021 by the author. Licensee MDPI, Basel, Switzerland. This article is an open access article distributed under the terms and conditions of the Creative Commons Attribution (CC BY) license (https:// creativecommons.org/licenses/by/ $4.0 /)$.
Faculty of Mining and Geoengineering, AGH University of Science and Technology, Mickiewicza 30 av., 30-059 Kraków, Poland; skrzypko@agh.edu.pl; Tel.: +48-126-172-160

\begin{abstract}
This article introduces a BackfillCAD model that relates to the determination of the backfilling time. The relationship of the individual model modules using a flow chart are characterized and presented. The main aim of the research was to determine the time of backfilling for the prospective deposits of zinc and lead ores in the Olkusz region in Poland. In the first stage of the research, laboratory tests were carried out on the backfilling mixture consisting of sand and water in a 1:1 volume ratio. In the laboratory tests, the content of grains below $0.1 \mathrm{~mm}$, the washability, water permeability, and compressibility of the backfilling mixture were determined. After the standard requirements were met by the backfilling mixture, the arrangement of one-way and bidirectional strip excavations was designed. In the next stages, by means of computer aided-design MineScape software, maximum thicknesses of the ore-bearing dolomite layer (T21_VI) for four geological crosssections were determined. The height of the first backfilled layer with a thickness of $5 \mathrm{~m}$ was analyzed. Taking into account the geometrical parameters of the strip - the maximum length and its width and height, as well as the capacity of the backfilling installation — this study calculated the backfilling times for the future strip excavations.
\end{abstract}

Keywords: hydraulic sand backfilling; BackfillCAD model; MineScape; strip mining

\section{Introduction}

Underground exploitation of useful minerals poses a number of problems related to the necessity to fill various types of voids. Some of them, such as the backfilling of goafs, due to their common use in underground mines, can be classified as basic issues in the field of mining technology [1]. Feng et al. [2] stated that solid backfilling mining is a green mining technology. Other cases of the necessity to use a backfilling result from the occurrence of failures related to the existing natural hazards, in particular rock bursts, or from special conditions and technology of exploitation, e.g., the need to maintain and strengthen the roadways. Zhang et al. [3] proved that backfilling reduces the risk of roof-caving face bursts. Wang et al. [4] pointed out the correct cooperation between geogrid and backfill surfaces even for saturated sand in the case of dynamic loading. Mining backfills are also used to eliminate shallow voids that pose a threat to surface structures. Fly ashes and cement materials are added to the filling mixture in order to improve strength parameters and to counteract surface subsidence [5]. On the other hand, Wang et al. [6] stated that the use of hydraulic backfilling is associated with high costs. The variety of special applications of backfillings makes it necessary to use different types and technologies. Lingga et al. [7] discovered shear strength envelopes for cemented rockfills, which play an important role in blasthole stopping and cut and fill mining methods. Sivakugan et al. [8] highlighted cemented and uncemented backfilling strategies in underground mining methods. Li et al. [9] proposed filling the post-excavation space with waste rocks in the longwall panel. Nujaim et al. [10] studied interaction of barricade and the backfill in relation to the mining excavation. Zhou et al. [11] suggested adding glass fibers to the cemented paste backfill in order to improve its properties. Hefni et al. [12] 
revealed that the new solution in the form of foam mine backfilling may be used in mines. Chen et al. [13] distinguished materials for hydraulic backfilling into river sand, hill sand, gravel, and gangue and stated that river sand is the best option in order to reduce subsidence. In turn, Huang et al. [14] divided solid backfilling mining materials into gangue, fly ash, aeolian sand, loess, and mineral waste residue. In some cases, technology is used to eliminate the post-mining space in the case of a highly gaseous rock mass [15]; in others, it is required to adapt, for example, pneumatic backfilling of shallow voids, or a completely separate technology is developed, for example, to minimize the impact of underground mining on the built-up area of the site [16]. Huang et al. [17] stated that backfilling material selection plays a special role in shallow depth. Filling the postexploitation voids is primarily aimed at equalizing the stress distribution in the whole bed loaded by roof rocks. The use of a backfilling strengthens the inter-room pillars. Mo et al. [18] strongly indicated correlation between cohesive and non-covesive backfilling in reference to coal pillar strength. Skrzypkowski [19], by means of numerical modelling, proved that sand backfilling contributes to the increase of the stability of excavations in the room and pillar methods. Backfilling is often used to extract thick deposits. Deng et al. [20] applied cemented backfilling during coal seam deposit with a thickness $21 \mathrm{~m}$, which was divided into six slices. Wu [21] stated that for medium-thick ore body, losses and dilution can be reduced by backfilling, especially for sublevel open stopping methods. Furthermore, cemented paste backfilling with aeolian sand in particular is used to recovery of the residual coal pillar [22]. Wang et al. [23] projected backfilling strip-mining technique under thick unconsolidated layers. Lu et al. [24] presented backfilling mining mode for strip in two stages of exploitation and liquidation. Under certain geological and mining conditions, mining methods with backfilling allow for obtaining greater output without leaving operational losses in comparison with strip methods [25]. Zhao et al. [26] stated that backfilling is particularly important in the case of strongly inclined deposits. The role of backfilling is to improve the stability of the roof conditions. Gonet et al. [27] pointed out that the backfilling process is sometimes carried out in a mixed manner, alone and with the addition of a cement binder. Raffaldi et al. [28] marked that in the underhand cut and fill mining method, the role of backfilling plays a significant role in maintaining the stability of excavations. Dzimunya et al. [29] presented several backfilling technologies to optimize pillar recovery.

Hydraulic backfilling is one of the technologies of filling post-exploitation voids, consisting in the transport of solids (backfilling material) by means of a stream of water in pipelines to the backfilled space [30]. Sivakugan [31] stated that hydraulic backfilling is characterized by good drainage characteristics. A mixture of backfilling materials with water is called a backfill mixture. After the mixture flows into the filling space, the materials sediment and the water flows into the drainage and treatment system. The backfill process continues until the material to be filled is completely filled. During the backfill process, a failure may occur due to clogging of the pipeline. Reasons for a backfilling failure can include non-mixed items entering the backfilling, excessive mixture density, pipeline rupture or gasket failure, insufficient flushing of the pipeline prior to the backfilling process or its late completion, damage to the pipeline by a rock fall, and the formation of air bags. The above-mentioned causes significantly contribute to the increase of the backfilling time; therefore, the formation of blockage is observed by the rapid growth of the mixture in the filling funnel. For the risk of blockage to be eliminated, the backfilling material must meet the requirements of standards and regulations. According to the Polish standard [32], there are three classes of backfilling material (Table 1), for which permissible values are defined. Non-combustible and non-toxic material can be used as filling materials: sand, gravel, slag, waste rock, industrial waste, and mixtures of various backfilling materials. 
Table 1. Physical properties of backfill materials based on the work of [32].

\begin{tabular}{|c|c|c|c|c|c|c|c|}
\hline \multirow[t]{2}{*}{ Material Class } & $\begin{array}{c}\text { The Content of } \\
\text { Particles of Size Less } \\
\text { than } 0.1 \mathrm{~mm} \text { (at Most) }\end{array}$ & $\begin{array}{c}\text { Maximal } \\
\text { Dimension of } \\
\text { Grains }\end{array}$ & $\begin{array}{c}\text { Compressibility } \\
\text { at Pressure } \\
15 \mathrm{MPa} \text { (at Most) }\end{array}$ & $\begin{array}{c}\text { Water- } \\
\text { Permeability } \\
\text { (Least) }\end{array}$ & $\begin{array}{l}\text { Washability } \\
\text { (at Most) }\end{array}$ & Bulk Density & \multirow{2}{*}{$\begin{array}{c}\text { The Content of } \\
\text { Visible Plant } \\
\text { Parts }\end{array}$} \\
\hline & $(\%)$ & $(\mathrm{mm})$ & $(\%)$ & $(\mathrm{cm} / \mathrm{s})$ & $(\%)$ & $\left(\mathrm{kg} / \mathrm{dm}^{3}\right)$ & \\
\hline $\begin{array}{l}\text { I } \\
\text { II } \\
\text { III }\end{array}$ & $\begin{array}{l}10 \\
15 \\
20\end{array}$ & 60 & $\begin{array}{c}5 \\
10 \\
15\end{array}$ & $\begin{array}{c}0.007 \\
0.002 \\
0.0004\end{array}$ & 20 & 1.3 & $\begin{array}{l}\text { It should not } \\
\text { content }\end{array}$ \\
\hline
\end{tabular}

The literature review showed a very small number of studies on the time of backfilling underground excavations. Regardless of the type of backfilling, the tests always concern determination of geotechnical parameters in laboratory conditions, numerical modelling, or industrial research on the behavior of excavations filled with backfilling material. In underground mining, computer-aided design programs are increasingly being used, which are equipped with modules for deposit modeling, mining methods, and scheduling. However, there is still some space to be developed related to the timing of backfilling. Therefore, the article presents for the first time a research model combining analytical calculations and laboratory tests with computer-aided design using the MineScape software. For the prospective zinc and lead ore deposit, this study modeled the deposition of rock mass layers. The thickness of the ore-bearing layer was determined with special distinction, for which mining blocks from 15 to $65 \mathrm{~m}$ long and from 15 to $55 \mathrm{~m}$ high were designed. Due to the shallow deposition of the ore deposit, about $71 \div 135 \mathrm{~m}$ below the ground surface, a series of laboratory tests was carried out with filling mixture, the purpose of which was to determine the material class. For the first time, sand with a grain size of $0.5 \mathrm{~mm}$ was used in the tests, which was also included in the analytical calculations. The use of the MineScape program made it possible to determine the places of arrangement of preparatory and operational excavations, for which the times of backfilling of strip excavations both in one-way and bidirectionally were calculated.

\section{BackfillCAD Model}

A very important factor in the success of a mining project related to the time of backfilling excavations is building an interdisciplinary model and adapting it to the intended goals. An important component of a correct model is to determine the relationship between individual studies. The model named BackfillCAD consists of four main modules (Figure 1). The first module deals with building a stratigraphic model using computer-aided design. On the basis of drilling cores taken from the prospective deposit region, this study determined the types of layers that make up the rock mass and the depth of their deposition. The drill holes database was then built and imported into MineScape. By using the stratigraphic module, this study was able to arrange the individual test holes for which the cross-sections were made. The main goal for these cross-sections was to determine the thickness of the orebearing layer between individual exploratory drill holes. The second module concerned the determination of the geometry of the strip or room excavation that will be backfilled. After determining the maximum allowable dimensions of the designed excavation, this study started its distribution on the cross-sections made in the MineScape program. The third module is related to laboratory testing of the backfilling mixture. The purpose of the tests was to determine the class of the filling material in accordance with the standard requirements. In particular, tests defined the content of grains below $0.1 \mathrm{~mm}$, in terms of the washability, water-permeability, and compressibility of the backfilling mixture. The fourth module of the BackfiillCAD model is related to the analytical calculations of the backfilling time. In particular, the difference in height between the inlet (surface coordinate) and the outlet (backfill coordinate) of the backfilling mixture must be determined. The shortest and longest flow paths of the backfilling are indicated by means of a stratigraphic model. The parameter, which is also closely related to laboratory tests, is the diameter of the sand grains, which is taken into account in the calculation of the critical velocity and the motion confidence index of the backfilling mixture. After the possibility of the motion of the backfilling mixture is determined, the next step is to determine the backfilling time. 


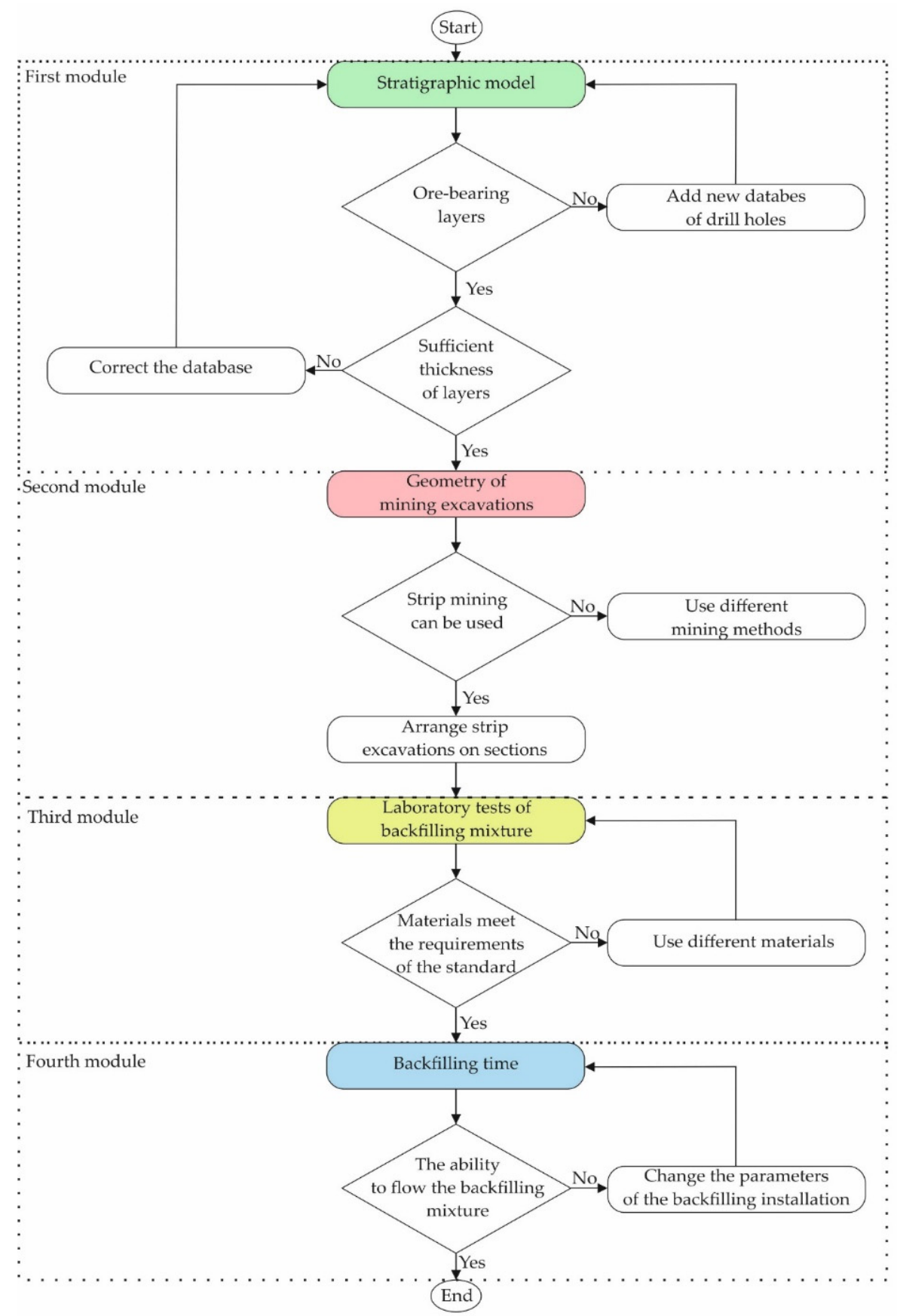

Figure 1. Flowchart for BackfillCAD model.

In designing a hydraulic backfilling for filling the post-mining space, this study's main task was to determine the efficiency of the backfilling installation, as well as the quality of the backfilling material and the flow conditions of the mixture. During the flow of the backfilling mixture, the solids are in a state of continuous or intermittent suspension, dispersed more or less evenly across the cross-section of the flows. Such a state can be achieved only during a turbulent flow of a mixture of solids and water, and the term kinetic specific gravity and volume concentration of the backfilling mixture can be used in relation to this. While the water itself can flow at a very low velocity, a flow velocity greater than the so-called critical velocity below which the solids begin to settle is necessary to keep the 
solids suspended in the water. The backfilling time for the post-exploitation space can be calculated according to Equation (1) [33]:

$$
\mathrm{B}_{\mathrm{t}}=\frac{\mathrm{V}_{\mathrm{s}}}{\mathrm{C}_{\mathrm{b}}}
$$

where

$\mathrm{B}_{\mathrm{t}}$-backfill time (h);

$\mathrm{V}_{\mathrm{s}}$-volume of the strip excavation $\left(\mathrm{m}^{3}\right)$;

$\mathrm{C}_{\mathrm{b}}$-capacity of the backfilling installation $\left(\mathrm{m}^{3} / \mathrm{h}\right)$, according to Equation (2);

$$
\mathrm{C}_{\mathrm{b}}=\mathrm{S} \cdot \mathrm{w}_{\mathrm{v}} \cdot 3600 \cdot \mathrm{q}
$$

where

S-cross-sectional area of the backfilling pipeline $\left(\mathrm{m}^{2}\right)$;

$\mathrm{w}_{\mathrm{v}}$-working velocity $(\mathrm{m} / \mathrm{s})$;

$\mathrm{q}$-coefficient of backfilling efficiency, $(\mathrm{q}=1.3424)$.

The value of $\mathrm{q}$ is the product of the coefficient 0.839 , which is used in Polish underground mines, and the average specific weight of the backfilling material.

In order for it to be concluded that the movement of the mixture in the backfilling installation will be possible, the motion confidence index (M) should be calculated according to Equation (3) With the value of $\mathrm{M}=1$, a slight increase in local resistance causes a reduction of the operating velocity below the critical value, contributing to the disturbance of operation or even blockage of the pipeline. Therefore, it is assumed that the minimum value of the $\mathrm{M}$ index for sand filling should be greater than the value of 1.1.

$$
\mathrm{M}=\frac{\mathrm{w}_{\mathrm{v}}}{\mathrm{c}_{\mathrm{v}}}
$$

where

$\mathrm{w}_{\mathrm{V}}$-working velocity $(\mathrm{m} / \mathrm{s})$, according to Equation (4);

$\mathrm{c}_{\mathrm{V}}$ - critical velocity $(\mathrm{m} / \mathrm{s})$.

$$
\mathrm{w}_{\mathrm{v}}=\sqrt{\frac{10^{4} \cdot \mathrm{U}_{\mathrm{el}}+2122.9-0.20578 \cdot \gamma_{\mathrm{k}}}{58.1-0.0013 \cdot \gamma_{\mathrm{k}}}},
$$

where:

$\mathrm{U}_{\mathrm{el}}$ - unit energy losses (Pa/s), according to Equation (5);

$$
\mathrm{U}_{\mathrm{el}}=\frac{\mathrm{h} \cdot \gamma_{\mathrm{k}} \cdot \alpha}{\mathrm{L}_{0}}
$$

where

$\mathrm{h}$-height difference of the inlet and outlet of the filling mixture (m);

$\alpha$-hydraulic efficiency factor of backfilling installation, $(\alpha=0.8),(/)$;

$\mathrm{L}_{0}$ - equivalent length of the backfilling installation (m);

$\gamma_{\mathrm{k}}$-kinetic specific gravity $\left(\mathrm{N} / \mathrm{m}^{3}\right)$.

For the quotient of $\mathrm{L}_{0}$ and $\mathrm{h}$ greater than 6.8 , the kinetic specific gravity is $1.8 \mathrm{kN} / \mathrm{m}^{3}$. However, for a value lower than 6.8, kinetic specific gravity is expressed in the following Equation (6):

$$
\gamma_{\mathrm{k}}=22715-695 \cdot \omega \text {, }
$$


where

$\omega$-parameter characterizing the spatial arrangement of the backfilling installation (/), according to Equation (7);

$$
\omega=\frac{\mathrm{L}_{0}}{\mathrm{~h}},
$$

Critical velocity $\left(c_{V}\right)$ of the flow filling mixture, taking into account the kinetic specific gravity of the feed and the maximum grain dimensions $\left(\mathrm{N} / \mathrm{m}^{3}\right)$, is expressed by the Equation (8):

$$
c_{v}=\frac{-8.491}{d+1.284}+5.04,
$$

where

$\mathrm{d}$-maximum grain size ( $\mathrm{mm})$.

\section{Laboratory Tests of the Backfilling Mixture}

Laboratory tests of the backfilling mixture were performed in the laboratories of the Faculty of Mining and Geoengineering, AGH University of Science and Technology in Kraków, Poland. The main goal of the research was to define the class of the backfilling material. Quartz sand was used in the tests. In particular, the research focused on determining sand grains below $0.1 \mathrm{~mm}$ and calculating the washability, water-permeability, and compressibility of the backfilling mixture.

\subsection{Determination of the Grains below $0.1 \mathrm{~mm}$}

Depending on the class of the backfilling material, the content of grains smaller than $0.1 \mathrm{~mm}$ should not exceed $20 \%$. Small fractions below $0.1 \mathrm{~mm}$ make it difficult for water to drain from the material deposited in the dammed post-exploitation space, extending the time of material settling and increasing the compressibility of the material. In extreme cases, the material behind the dam may exist in the form of a liquid, for a long period of time, exerting a large pressure on backfilling dams and creating a risk of damaging the dams and flooding active mine workings. In addition, fine material fractions are washed away by the draining backfilling water and the field settling tanks are quickly filled with sludge. The average content of grains with dimensions below $0.1 \mathrm{~mm}$ was determined using an Analyzer 22 MicroTec Plus laser gauge (Idar-Oberstein, Germany), which enables the examination of particle sizes from 0.08 to $2000 \mu \mathrm{m}$ [34]. The measurement results are presented in Table 2 and in Figure 2a-c.

Tests 1, 2, and 3 were performed on samples of the same sand. As the results of the tests were very similar, the tests were repeated only three times. From Table 2, it can be seen that the average percentage contribution of particles for $0.1 \mathrm{~mm}$ grain class was $1.2 \%$, and the average cumulative percentage contribution of particles was $9.7 \%$. The average cumulative percentage contribution of particles for a specific grain class was calculated by adding the average percentage contribution of particles to the value of average cumulative percentage contribution of particles from the previous row. On the basis of the obtained results, this study concluded that the tested sand met the requirements presented in Table 1 with regard to the grain content below $0.1 \mathrm{~mm}$. For the first class of backfill material, the tested sand was characterized by an almost 10 times lower value.

\subsection{Determination of the Washability of the Backfilling Material}

The washability of the material was determined in a tubular container with a diameter of $150 \mathrm{~mm}$ and a length of $500 \mathrm{~mm}$ (Figure 3). The container was blind on one side and had a sealing lid on the other. After the material sample was dried at $105^{\circ} \mathrm{C}, 2000 \mathrm{~g}$ of sand was weighed and mixed with water in a 1:1.5 volume ratio. This mixture was poured into a container. The closed container was then placed on a shaker at 200 strokes/min and shaken for a period of $30 \mathrm{~min}$. 
Table 2. Grain distribution.

\begin{tabular}{|c|c|c|c|c|c|c|}
\hline $\begin{array}{c}\text { Particle Class, } x, \\
(\mu \mathrm{m})\end{array}$ & $\begin{array}{l}\text { Average Cumulative Percentage } \\
\text { Contribution of Particles in } \\
\text { Respective Grain Class, Q3(x), (\%) }\end{array}$ & $\begin{array}{c}\text { Standard Deviation } \\
\text { from Three Tests, } \\
\text { CV, (\%) }\end{array}$ & Test No. 1 & Test No. 2 & Test No. 3 & $\begin{array}{c}\text { Average Percentage } \\
\text { Contribution of Particles } \\
\text { in Respective Grain Class, } \\
\text { dQ3 }(x),(\%)\end{array}$ \\
\hline 0.5 & 0.4 & 11 & 0.4 & 0.4 & 0.5 & 0.4 \\
\hline 1 & 1.1 & 9.6 & 1.1 & 1 & 1.2 & 0.7 \\
\hline 2 & 2.3 & 9.8 & 2.3 & 2 & 2.6 & 1.2 \\
\hline 4 & 3.7 & 10.7 & 3.6 & 3.2 & 4.3 & 1.4 \\
\hline 6 & 4.4 & 10.6 & 4.2 & 3.9 & 5 & 0.7 \\
\hline 8 & 4.9 & 10.5 & 4.7 & 4.4 & 5.6 & 0.5 \\
\hline 10 & 5.4 & 10.6 & 5.1 & 4.8 & 6.1 & 0.5 \\
\hline 11 & 5.6 & 10.6 & 5.4 & 5 & 6.4 & 0.2 \\
\hline 12 & 5.8 & 10.6 & 5.6 & 5.2 & 6.7 & 0.2 \\
\hline 14 & 6.3 & 10.4 & 6.1 & 5.6 & 7.2 & 0.5 \\
\hline 16 & 6.7 & 10.1 & 6.6 & 6 & 7.6 & 0.4 \\
\hline 18 & 7.1 & 9.7 & 6.9 & 6.3 & 8 & 0.4 \\
\hline 20 & 7.3 & 9.4 & 7.2 & 6.5 & 8.2 & 0.2 \\
\hline 25 & 7.5 & 8.9 & 7.4 & 6.8 & 8.4 & 0.2 \\
\hline 30 & 7.5 & 8.8 & 7.4 & 6.8 & 8.4 & 0.0 \\
\hline 35 & 7.5 & 8.8 & 7.4 & 6.8 & 8.4 & 0.0 \\
\hline 40 & 7.5 & 8.8 & 7.4 & 6.8 & 8.4 & 0.0 \\
\hline 45 & 7.5 & 8.8 & 7.4 & 6.8 & 8.4 & 0.0 \\
\hline 63 & 7.5 & 8.7 & 7.4 & 6.8 & 8.4 & 0.0 \\
\hline 71 & 7.6 & 8.5 & 7.5 & 6.9 & 8.5 & 0.1 \\
\hline 80 & 7.9 & 7.9 & 7.7 & 7.2 & 8.7 & 0.3 \\
\hline 90 & 8.5 & 7.0 & 8.3 & 7.9 & 9.3 & 0.6 \\
\hline 100 & 9.7 & 6.0 & 9.4 & 9.1 & 10.5 & 1.2 \\
\hline 120 & 13.4 & 4.2 & 13.1 & 12.9 & 14.2 & 3.7 \\
\hline 140 & 18.1 & 3.0 & 17.9 & 17.6 & 18.9 & 4.7 \\
\hline 160 & 22.8 & 2.3 & 22.6 & 22.2 & 23.5 & 4.7 \\
\hline 180 & 26.9 & 1.9 & 26.8 & 26.3 & 27.6 & 4.1 \\
\hline 200 & 30.7 & 1.5 & 30.7 & 30.2 & 31.3 & 3.8 \\
\hline 250 & 43.4 & 0.8 & 43.3 & 43.1 & 43.9 & 12.7 \\
\hline 300 & 61.3 & 0.4 & 61 & 61.1 & 61.6 & 17.9 \\
\hline 350 & 78.4 & 0.3 & 78.2 & 78.4 & 78.7 & 17.1 \\
\hline 400 & 89.5 & 0.2 & 89.3 & 89.4 & 89.7 & 11.1 \\
\hline 500 & 100 & 0 & 100 & 100 & 100 & 10.5 \\
\hline
\end{tabular}

After the end of shaking (washing), the contents of the container were placed on a sieve with a capacity of $4 \mathrm{dm}^{3}$ and mesh size of $0.1 \mathrm{~mm}$ and washed with water. The sieve residue was dried at $105^{\circ} \mathrm{C}$ and weighed to the nearest $0.01 \mathrm{~g}$. The content of grains $\left(G_{c}\right)$ with dimensions below $0.1 \mathrm{~mm}$ was calculated according to Equation (9). The results of five measurements are shown in Figure 4.

$$
G_{c}=\frac{m-m_{s}}{m} \cdot 100[\%],
$$

where

$m$-weight of the sample to be screened, (g);

$m_{s}$-weight of the residue on the sieve, $(\mathrm{g})$.

The mean content of grains $\left(G_{c}\right)$ smaller than $0.1 \mathrm{~mm}$ for a sample of $2000 \mathrm{~g}$ was $0.25 \%$. The washability of the backfilling material was much less than $20 \%$; therefore, the requirements of Table 1 were met.

\subsection{Determination of the Compressibility of the Backfilling Mixture}

Compressibility refers to the change in the height of the backfilling layer under load. The compressibility of the material was determined in an oedometer. Holes with a diameter of $2 \mathrm{~mm}$ were made in the bottom of the oedometer to allow drainage of water from the backfilling mixture. The sand was mixed with water. The mixture prepared in this way was poured into the cylinder of the oedometer (Figure 5a) to the height (h) (Figure 5b). Then, the cylinder with the piston was placed in the testing machine (Figure $5 \mathrm{c}$ ). The sample was loaded with a load increase of about $0.04 \mathrm{MPa} / \mathrm{s}$. The tests were performed for five samples, each time recording the change in height at a given load level. The sample was a mixture of sand and water in a 1:1 volume ratio. Sand with a grain size of up to $0.5 \mathrm{~mm}$ was mixed with water with a temperature of $12{ }^{\circ} \mathrm{C}$. One day before the tests, sand and water were placed in the oedometer. After this time, the water was filtered through the sand and then the compressibility tests were started. In each case, the distance between the top plane of the backfilling mixture and the cylinder did not exceed $10 \mathrm{~mm}$. The measurement results are shown in Figure 6. 


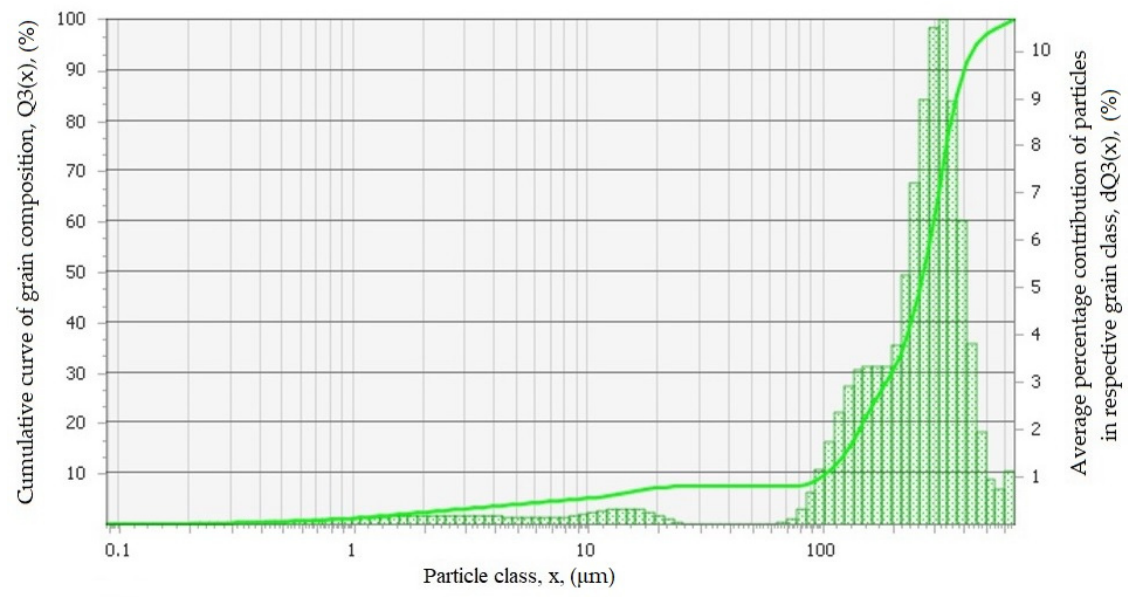

- Average percentage contribution of particles in respective grain class - Cumulative curve of grain composition

(a)

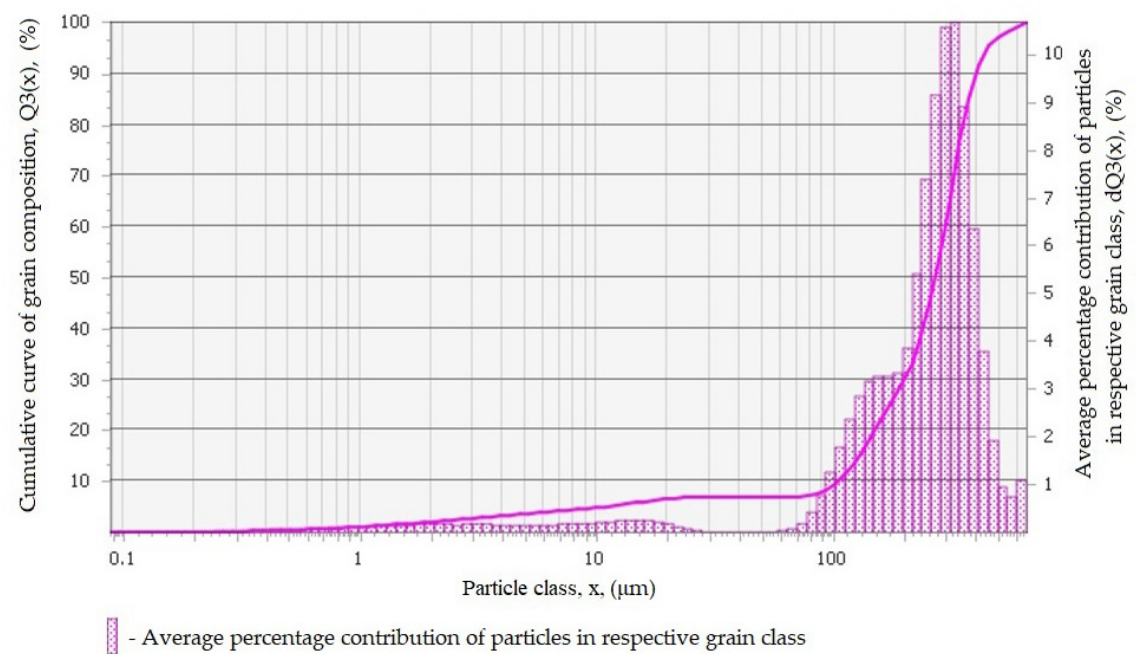

- Cumulative curve of grain composition

(b)

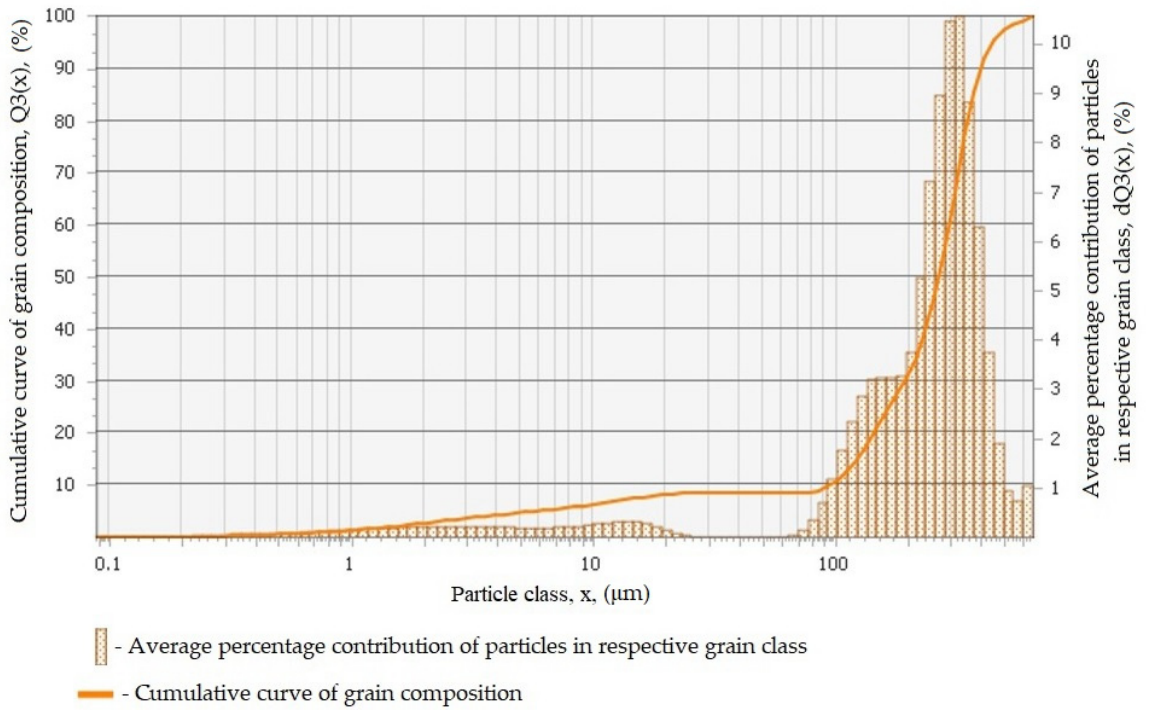

(c)

Figure 2. Particles distribution curve for (a) test no. 1; (b) test no. 2; (c) test no. 3. 


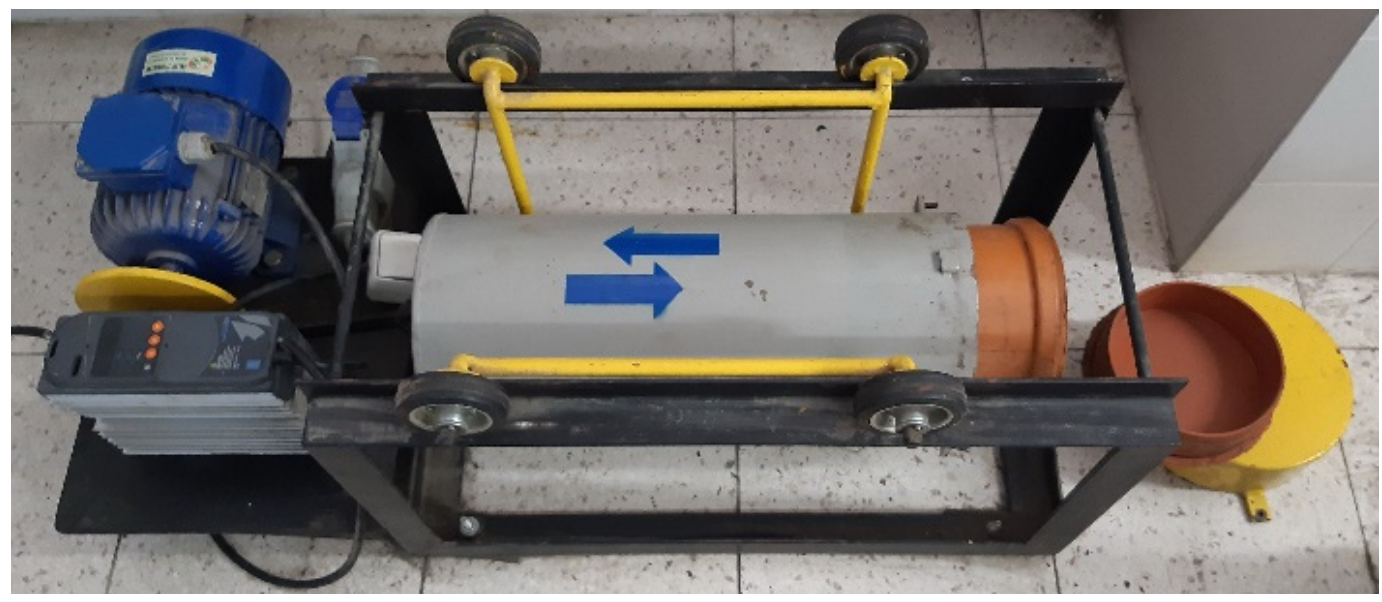

Figure 3. Laboratory shaker.

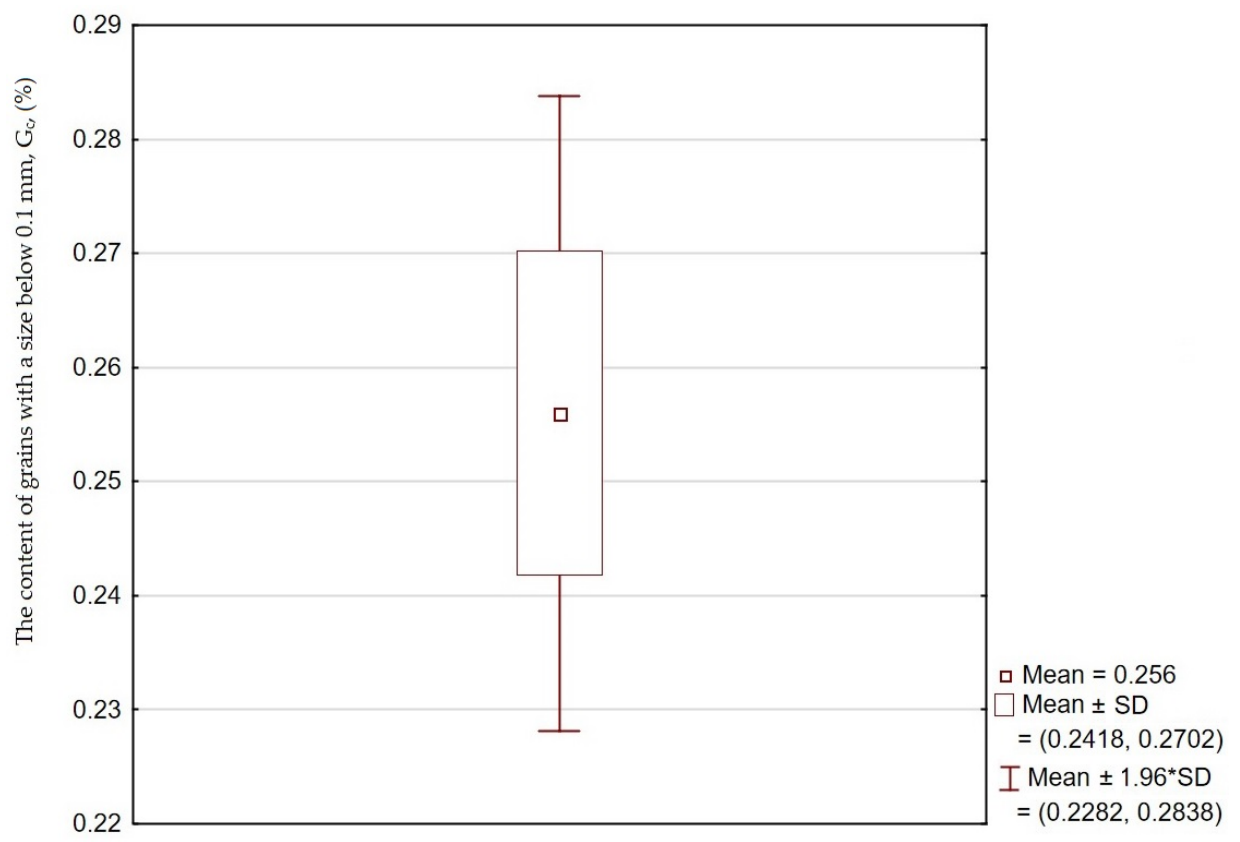

Figure 4. Content of grains less than $0.1 \mathrm{~mm}$.

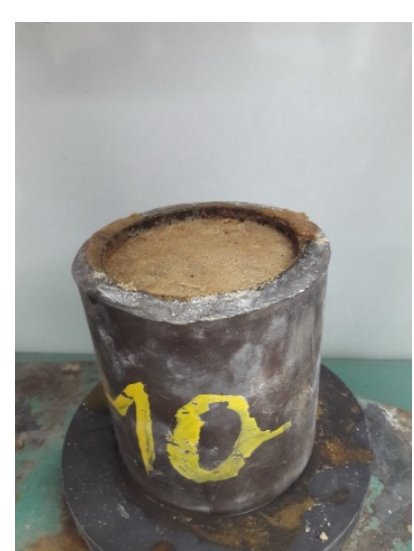

(a)

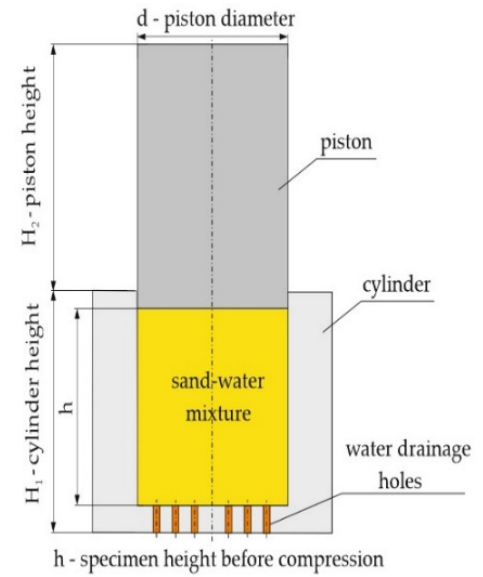

(b)

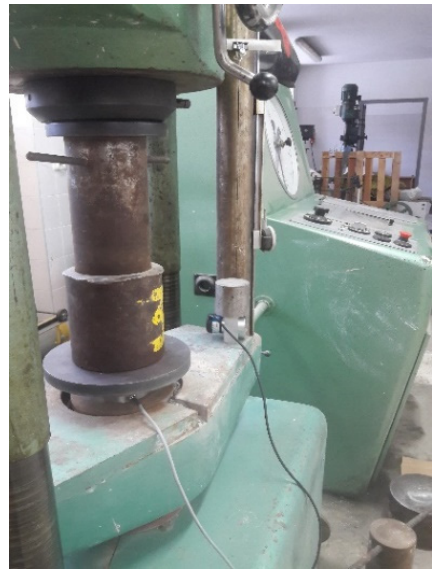

(c)

Figure 5. Compressibility test of the backfilling mixture: (a) general view of the filled cylinder; (b) elements of the oedometer; (c) compression test of the mixture by means of oedometer. 


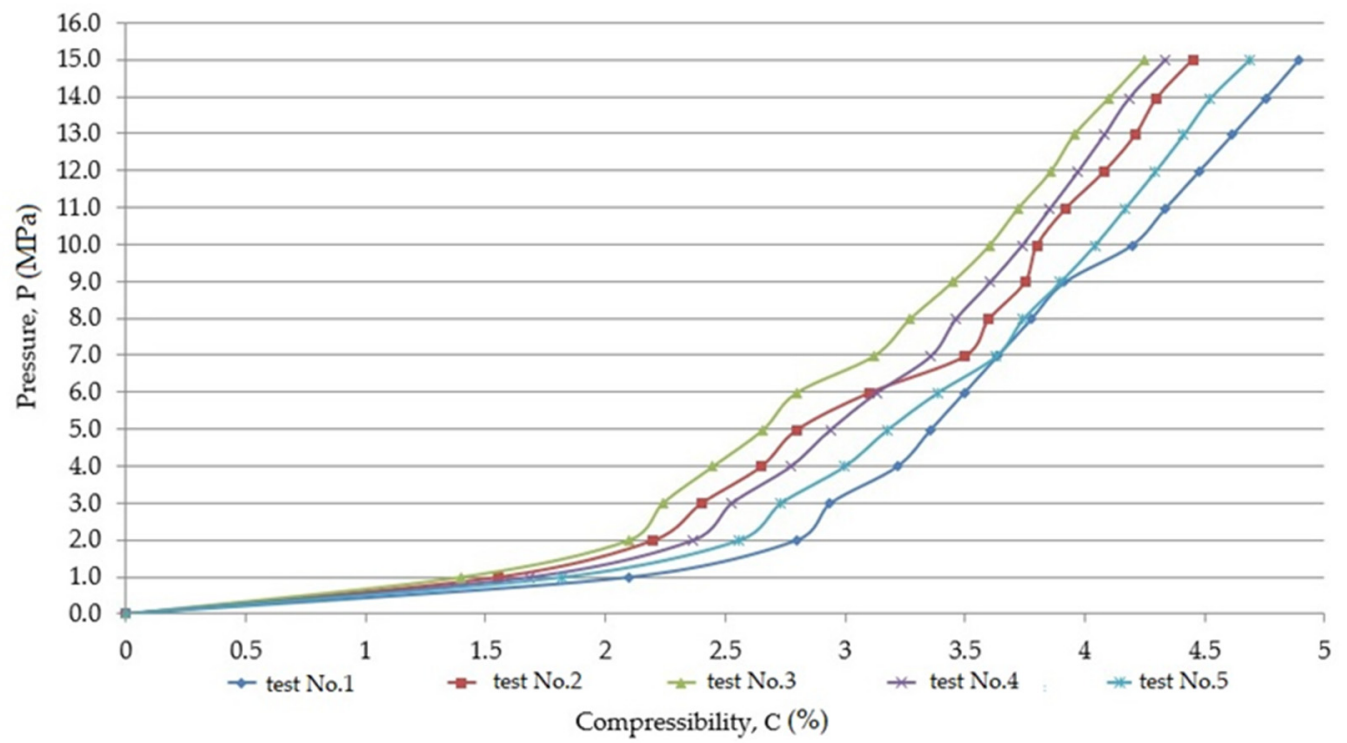

Figure 6. Pressure/compressibility characteristics of the backfilling mixture.

The average value of the compressibility of the backfilling mixture at a pressure of $15 \mathrm{MPa}$ was $4.5 \%$. Such a result means that the material was included in the first class of backfilling material, according to Table 1 .

\subsection{Determination of the Water Permeability of the Backfilling Material}

Water permeability is the ability of water to flow through a cross-section of a backfilling mixture per unit time. It is expressed in centimeters per second. The higher the water permeability value, the faster the water drains from the sand. At high values above $0.04 \mathrm{~cm} / \mathrm{s}$, the mixture flowing out of the pipeline has a limited range of spreading in the post-exploitation space. Characteristic mounds of backfilling material form at the outlet. During the flow of the backfilling mixture, the solids are in a state of continuous or intermittent suspension, dispersing more or less evenly across the cross section of the flowing streams. This state can only be achieved during a turbulent flow of a mixture of solids (sand) and water, which is related to the volume concentration of the backfilling mixture. While the water itself can flow very slowly, a flow velocity greater than the critical velocity below which the solids (sand) begin to settle is necessary to keep the solids (sand) suspended in the water. Hence, the critical flow velocity of the backfilling mixture is essential for the reliability of the backfilling installation. The lower the water permeability values, the more favorable is the spread of the mixture and the tighter the filling of the post-mining space. With water permeability below $0.0004 \mathrm{~cm} / \mathrm{s}$, the material is difficult to filter and cannot be classified as a backfilling material. Water permeability tests were performed in a special measuring cylinder (Figure 7a,b). First, a sample of the backfilling mixture was poured into the inner cylinder. Then, after the surface of the deposited material was levelled, it was covered with a sieve with $0.5 \mathrm{~mm}$ square meshes and loaded with a weight of $5000 \mathrm{~g}$. One hour after sample preparation, water was supplied through the inlet tube, keeping the water level $200 \mathrm{~mm}$ higher than the surface of the filling mixture in the cylinder. The excess water was drained off through the overflow pipe. On the other hand, the water from the outer cylinder was filtered through the tested material sample and through the drainpipe, and then it was collected in the measuring cylinder. One test lasted $60 \mathrm{~min}$, during which the volume of filtered water was recorded every $10 \mathrm{~min}$. The measurement results are shown in Figure 8. The water permeability was calculated according to Equation (10):

$$
\mathrm{WP}=\frac{\mathrm{W}_{\mathrm{v}}}{\mathrm{I}_{\mathrm{c}} \cdot \mathrm{t} \cdot \mathrm{h}_{\mathrm{p}} \cdot\left(0.7+\alpha \cdot \mathrm{t}_{\mathrm{W}}\right)},
$$


where

WP-water permeability, $(\mathrm{cm} / \mathrm{s})$;

$\mathrm{W}_{\mathrm{v}}$-water volume, $\left(\mathrm{cm}^{3}\right)$;

$\mathrm{I}_{\mathrm{C}}$-inner cylinder cross-sectional area, $\left(\mathrm{cm}^{2}\right)$;

t-test time, (s);

$\mathrm{h}_{\mathrm{p}}$-hydraulic drop, (/);

$\alpha$-change in water viscosity with a temperature change by $1{ }^{\circ} \mathrm{C},\left(1 /{ }^{\circ} \mathrm{C}\right)$, according to Equation (11);

$$
\alpha=0.03 \cdot \frac{1}{t_{w}-10}
$$

where

$t_{w}$-water temperature, $\left({ }^{\circ} \mathrm{C}\right)$.

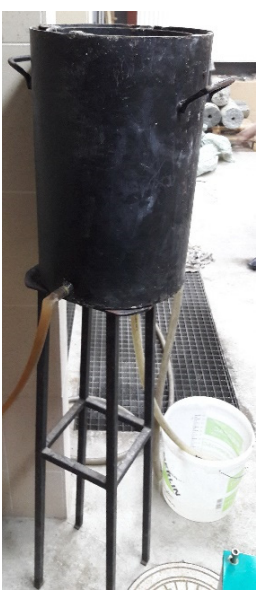

(a)

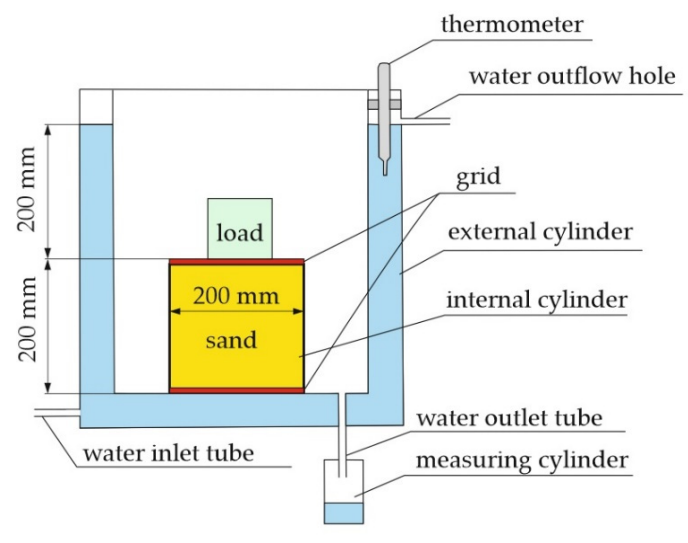

(b)

Figure 7. Measuring cylinder for testing water permeability: (a) general view; (b) cylinder components.

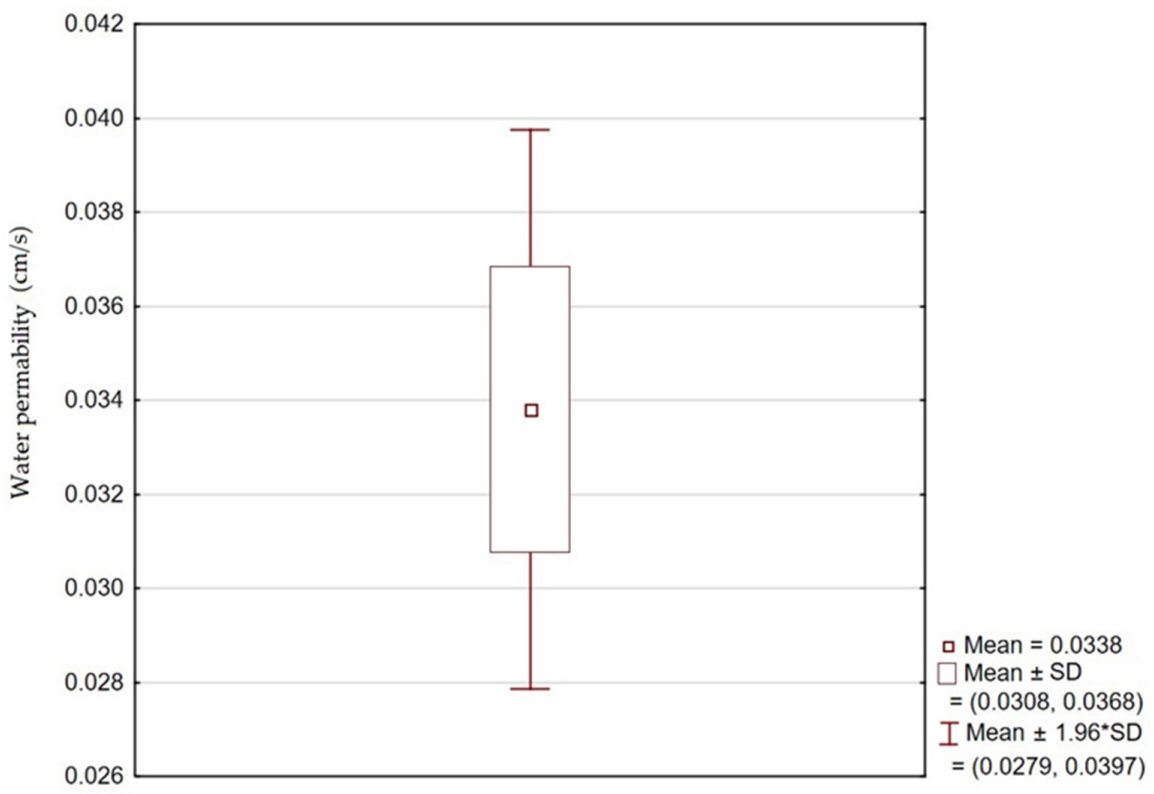

Figure 8. Mean and standard deviation for the water-permeability tests.

The mean value of the water permeability was $0.033 \mathrm{~cm} / \mathrm{s}$. The obtained value qualified the backfilling material to the first class, according to Table 1. 


\section{Backfilling Time for the Future Exploitation Area and Discussion}

The deposits of zinc and lead ores in the Olkusz region in Poland have the form of a lens and a pocket. Only the deposits that can be exploited for economic benefit under the existing geological and mining conditions are of economic importance and industrial value. In the case of zinc and lead ore deposits, it is very important to identify the deposit on the basis of which further stages related to preparation and operation can be started. It should be considered that a deposit is not suitable for favorable exploitation if the amount of ore in the deposit is small or if the ore contains too little metal. In the case of the exploitation of zinc and lead ore deposits in Poland, the metal content often changes in individual parts of the deposit (from 1.5\% to 3\%). On the basis of the exploratory holes made in the Olkusz region, the distribution of individual layers of the rock mass was modeled. MineScape software (Denver, CO, United States of America) in a version 7 was used for modeling, which is more and more often used in underground mining [35]. A characteristic feature of the MineScape program is, inter alia, its modular structure, which includes creating the geometry of excavations, importing data from various graphic programs and building stratigraphic and block models. Individual modules can operate independently, contributing to the division of duties and assigning tasks for specialists responsible for planning and scheduling mining works. One of the greatest advantages of the program is the possibility of visualizing the spatial arrangement of exploratory drill holes or the entire structure of the mine, including access, preparatory excavations, and mining excavations. Moreover, the program includes functions that make it possible to model discontinuous deformations in the form of faults [36]. First, a future research area with 21 exploratory drill holes was selected. The area was $1000 \mathrm{~m} \times 1000 \mathrm{~m}$. For this area, drill hole coordinates were entered into MineScape (Figure 9). The ore deposit named Laski 1 is located in the Olkusz poviat in close proximity to the Pomorzany deposit. The geological resources of the deposit documented in the $\mathrm{C} 1$ and $\mathrm{C} 2$ categories total 10.76 million $\mathrm{Mg}$ of zinc and lead ore, including $424.86 \times 10^{3} \mathrm{Mg}$ of zinc and $67.81 \times 10^{3} \mathrm{Mg}$ of lead [37].

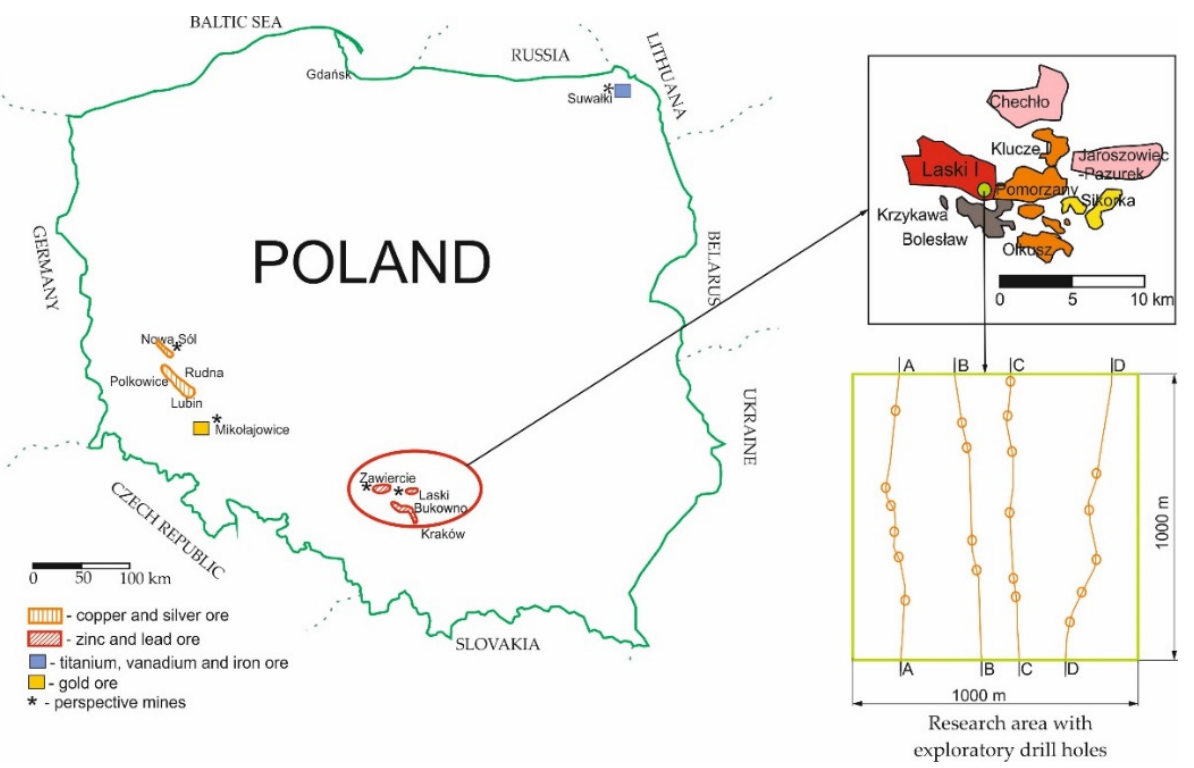

Figure 9. Research area.

In the selected research area, cross-sections through drill holes A-A, B-B, C-C, and D-D were made, on which the thicknesses of the ore-bearing dolomite layers (layer T21_VI) were marked (Figure 10a-d). Ore-bearing dolomites occur in the form of gray, fine-crystalline dolomites with an uneven fracture. In the oxidized zones, dolomites are strongly broke, and the voids and fissures are partially or completely filled with zinc, lead, and iron sulfides, as well as waste minerals such as vein calcite; dolomite; and, less frequently, barite and grenocite. In addition, the sections show mining blocks, the width of which included 
one strip in a one-way direction and bidirectionally, and the width of a haulage room equal to $5 \mathrm{~m}$. Moreover, it was assumed that the thick orebody would be exploited in horizontal layers with a thickness of $5 \mathrm{~m}$. The length of the strip $\left(\mathrm{L}_{\mathrm{s}}\right)$, which was equal to the maximum step of backfill, was calculated according to Equation (12) [38]:

$$
L_{s}=\sqrt{\frac{h_{1} \cdot \gamma_{1}+h_{2} \cdot \gamma_{2}}{h_{1} \cdot \gamma_{1}}+\left[\frac{b_{s} \cdot h_{1}^{2}}{6 \cdot\left(h_{1} \cdot \gamma_{1}+h_{2} \cdot \gamma_{2}\right)}-0.7\right]},
$$

where

$\mathrm{L}_{\mathrm{s}}$-length of the strip excavation (backfilling length) (m);

$\mathrm{h}_{1}$-thickness of the direct roof rocks $(\mathrm{m})$;

$\mathrm{h}_{2}$-thickness of the overburden rocks $(\mathrm{m})$;

$\gamma_{1}$-unit weight of the direct roof $\left(\mathrm{MN} / \mathrm{m}^{3}\right)$;

$\gamma_{2}$-unit weight of the overburden rocks $\left(\mathrm{MN} / \mathrm{m}^{3}\right)$;

$\mathrm{b}_{\mathrm{s}}$ - bending strength of the direct roof rocks $\left(\mathrm{b}_{\mathrm{s}}=4.62\right)$, (MPa).

For the strip with length of $30 \mathrm{~m}$, this study assumed that the block width for a one-way exploitation was $35 \mathrm{~m}$ (Figure 11a), while for bidirectional mining it was equal to $65 \mathrm{~m}$ (Figure 11b). However, the width of the strip $\left(W_{s}\right)$ was calculated according to Equation (13):

$$
W_{s}=\left(2.4 \cdot \operatorname{ctg} \delta+0.2 \cdot \varepsilon \cdot \sqrt{\frac{C_{s} \cdot a_{1}}{\gamma}}\right) \cdot \frac{1}{\cos \alpha},
$$

where

$W_{s}$-width of the strip excavation, (m);

$\delta$-rock refraction angle for mines in the Olkusz region $(\delta=60),\left(^{\circ}\right)$;

$\varepsilon$-creep coefficient for deposit rocks $(\varepsilon=0.8),(-)$;

$C_{s}$-compressive strength of the direct roof $\left(C_{s}=35\right)(\mathrm{MPa})$;

$a_{1}$-distance between the main fissure systems $\left(a_{1}=0.4\right),(\mathrm{m})$;

$\gamma$-unit weight of the direct roof $(\gamma=0.026)\left(\mathrm{MN} / \mathrm{m}^{3}\right)$;

$\cos$ - cosine trigonometric function;

$\alpha$-the angle of inclination of the stratification $(\alpha=5),\left({ }^{\circ}\right)$.

The strip width was $5.11 \mathrm{~m}$. For further calculations, the result was rounded down to $5 \mathrm{~m}$.

Depending on the extent of dolomitization, the average thickness of ore-bearing dolomites determined in the MineScape program was very variable and ranged from 15 to $55 \mathrm{~m}$. The bottom of the T21_VI layer was also located at different depths. The maximum depth of deposition was $136.8 \mathrm{~m}$, while the lowest was $69.1 \mathrm{~m}$. Due to the shallow deposition of the deposit, this study required the use of mining systems with roof protection. For this purpose, the mixture of sand and water, which is a hydraulic backfill, was tested in laboratory conditions. In the backfilling time calculation for the strip-mining method, this study assumed that the backfilling mixture would be transported in a $150 \mathrm{~mm}$ diameter backfilling pipeline. From the $130 \mathrm{~m}$ long backfilling shaft, the mixture would be transported by gravity to the $250 \mathrm{~m}$ long drift. Then, the mixture would flow to the transportation roadway, which would be connected to four inclined drifts spaced from each other every $250 \mathrm{~m}$. From four inclined drifts, each $500 \mathrm{~m}$ long, haulage room would be made (Figure 12), from which one-way or bidirectional strip excavations would be made. 


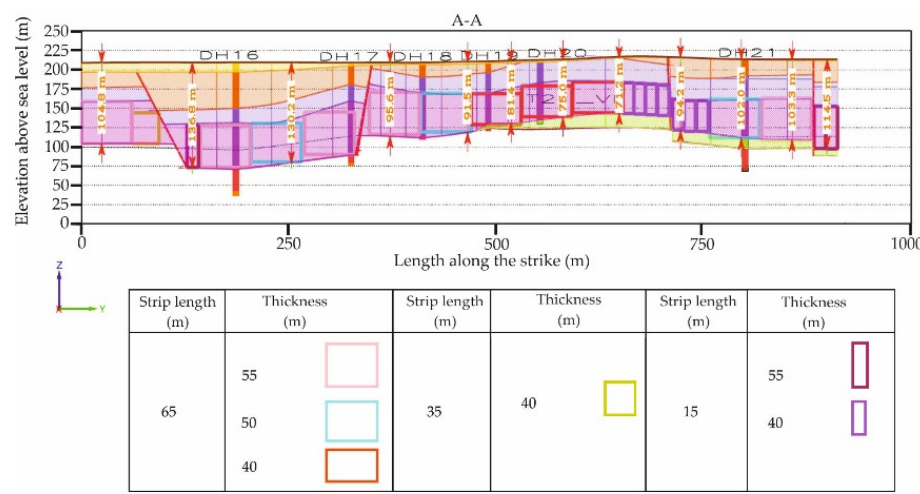

(a)

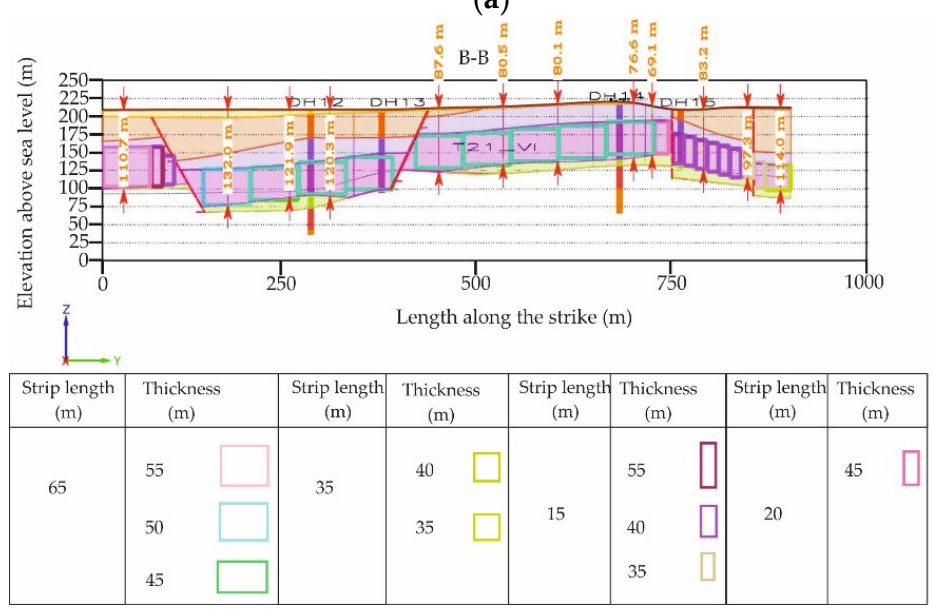

(b)
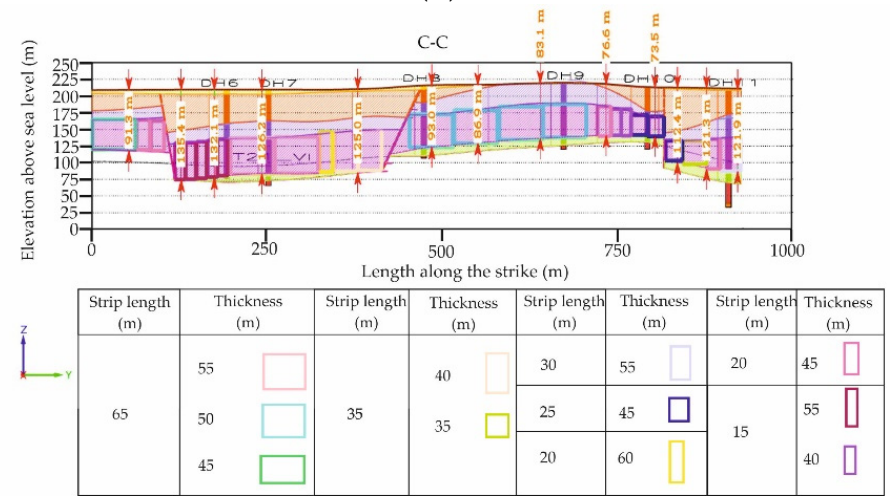

(c)
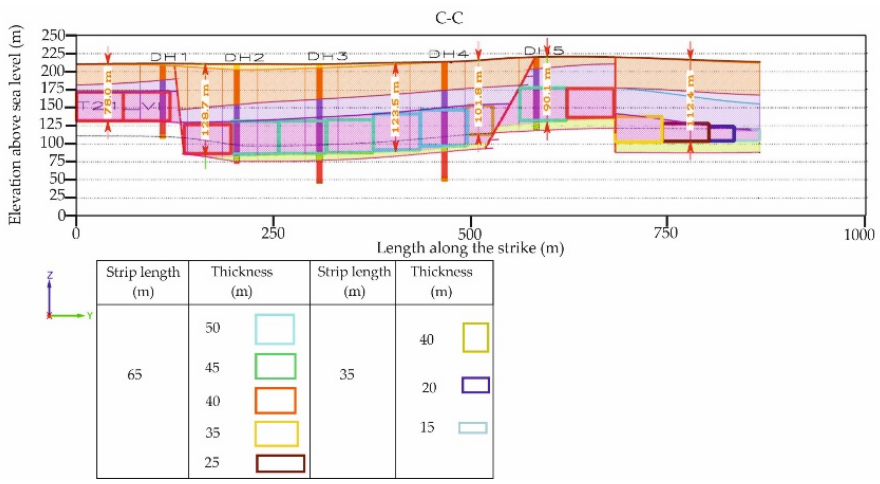

(d)

Figure 10. Cross-section through the exploratory drill holes: (a) A-A section; (b) B-B section; (c) C-C section; (d) D-D section; T21_V1—ore-bearing dolomites; DH1-21—numbers of drill holes. 


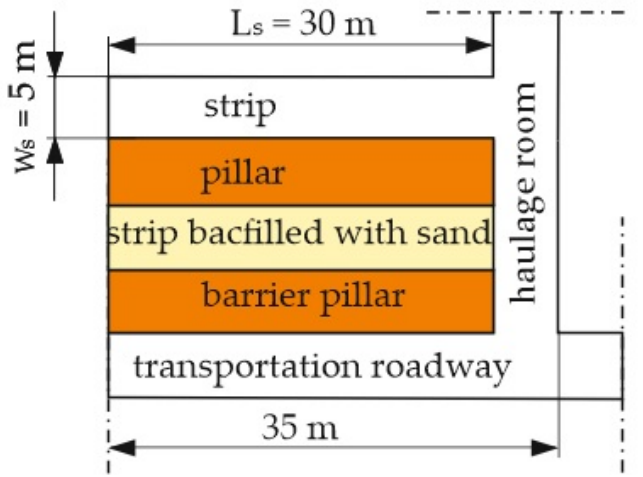

(a)

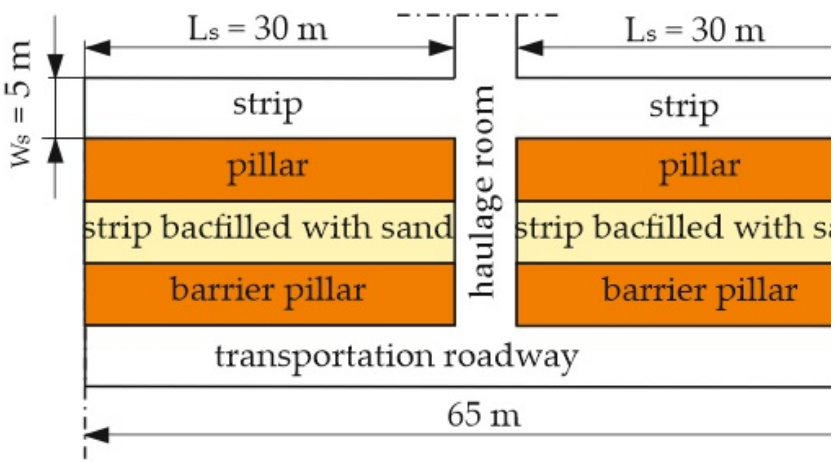

(b)

Figure 11. Block diagram of the strip-mining excavation: (a) one-way; (b) bidirectional.

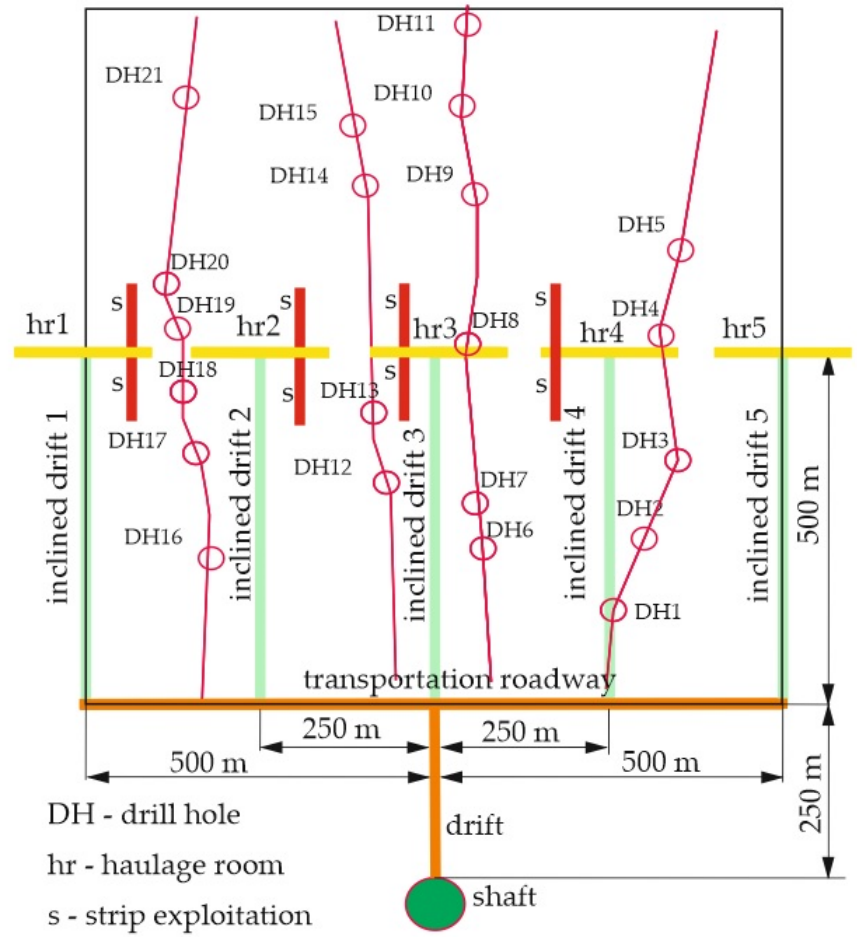

Figure 12. Structure scheme with mining excavations.

The calculations assumed that the operation would start from half of the future production block. For sections A-A, B-B, C-C, and D-D (Figure 10a-d), the mean depths of deposition were $91.5,120.3,93$, and $123.5 \mathrm{~m}$, respectively. For these depths, the backfilling times were calculated, taking into account the length of the strips 15,20,25, 30, 35, and $65 \mathrm{~m}$. The data for the calculations were placed in Equation (1). The results of the calculations are shown in Figure 13.

Comparing the average depths of the ore-bearing dolomite layer presented in Figure $10 a-d$, this study found that for the sections A-A and C-C, the depths were practically the same. The difference was only $1.5 \mathrm{~m}$. A similar situation can be observed for sections B-B and D-D, where the difference was only $3.2 \mathrm{~m}$. It would seem that the filling times should be similar. Meanwhile, the backfilling time depended directly on the number of preparatory excavations. On the basis of Figure 11, one can conclude that the backfilling time for the driving excavation for the A-A cross-section was $24.56 \%$ greater in relation to the $\mathrm{C}-\mathrm{C}$ cross-section. It was directly related to the longest distance that the backfilling mixture must travel from the shaft to the placement site. In the case of the B-B and D-D sections, the difference was significantly smaller. The backfilling time for the B-B section was 
$13.1 \%$ shorter than for the D-D section. Very similar times for backfilling were obtained for the B-B and C-C sections. The difference was only 2.33\%. Despite the significant difference in the height of the deposit, over $27 \mathrm{~m}$, the decisive parameter determining the backfilling time was the length of the installed pipelines.

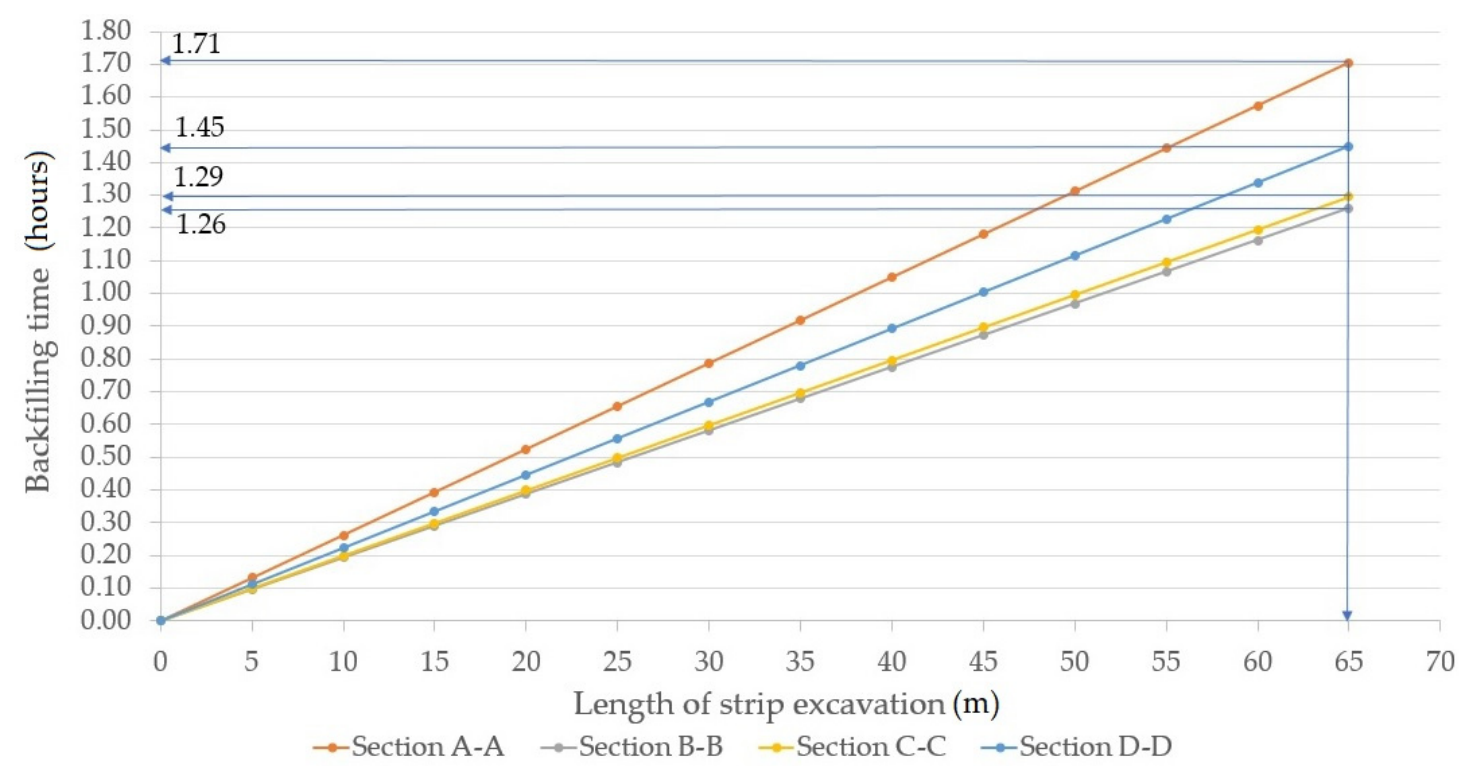

Figure 13. Time-length characteristics for average depth in relation to sections: A-A, B-B, C-C, and D-D.

Exploitation of a single layer of the deposit causes deformations of the terrain surface, the size of which is a function of the surface of the exploited deposit, depth, and thickness of the layer. For a specific method of liquidation of the post-exploitation space, the coefficients characterizing the influence of exploitation on the ground surface should be determined. In engineering calculations, this most often includes values of the maximum subsidence, slope, and horizontal deformation of the terrain. In order to calculate these values, one must know the exploitation coefficient and the angle of the main influence range. In the conditions of underground exploitation of zinc and lead ore deposits with a hydraulic backfilling in the Olkusz region, these parameters were equal to 0.15 and $60^{\circ}$, respectively [38]. Calculating the terrain inclination by dividing the maximum subsidence (the product of exploitation coefficient and the thickness of selected layer) and the radius range of principal influence (the quotient of the depth of exploitation and the tangent of angle of the main influence range), one finds that for the shallowest and the deepest mining of $69.1 \div 136.8 \mathrm{~m}$ (Figure 10) for selecting the first layer with a thickness of $5 \mathrm{~m}$, the inclination values will be 18.79 and $9.49 \mathrm{~mm} / \mathrm{m}$ for the shallowest and deepest exploitations, respectively. The permissible inclination values for the third category of surface protection ranged from 5 to $10 \mathrm{~mm} / \mathrm{m}$, while for the fifth category, they were values above $15 \mathrm{~mm} / \mathrm{m}$ [39]. The fifth category of surface protection concerns undeveloped areas, i.e., forests and meadows, while the first category had the greatest restrictions (historic buildings). Mining thick deposits of zinc and lead ores lying at shallow depths requires the division of the deposit into layers so as to accurately fill the post-mining space. It is worth noting that the selection of subsequent layers is significantly delayed in time, which contributes to the gradual delamination of the roof, which is often the reason why it is difficult to select higher layers. The use of a hydraulic backfilling to use in the post-mining space undoubtedly stiffens the spatial structure and reduces the deformation of the main roof and contributes to the reduction of surface deformation. Nevertheless, the surface protection categories should be taken into account and the exploitation system should be adjusted to the limit values. 


\section{Conclusions}

The article presents the BackfillCAD model, which is a combination of analytical laboratory tests and computer-aided design, the purpose of which is to determine the backfilling time. By combining the various stages of the research, this study specified four characteristic modules: stratigraphic, geometry of strip excavations, laboratory tests of the backfilling mixture, and the backfilling time. The original contribution to the research was the creation of a model for the backfilling process adequately to the level of deposit recognition and, above all, the performance of tests minimizing the risk associated with the incorrect selection of the backfilling material. The model provides the basis for planning and organizing the preparation of the deposit for exploitation, and therefore it has a direct impact on the method of managing the process of backfilling in post-mining areas.

On the basis of the laboratory tests for the backfilling mixture consisting of sand with a grain size of $0.5 \mathrm{~mm}$ and water in a 1:1 volume ratio, this study concluded that

- The average percentage contribution of particles for $0.1 \mathrm{~mm}$ grain class was $1.2 \%$ and the average cumulative percentage contribution of particles was $9.7 \%$;

- The average value of the compressibility of the backfilling mixture at a pressure of $15 \mathrm{MPa}$ was $4.5 \%$;

- The mean value of the water-permeability was $0.033 \mathrm{~cm} / \mathrm{s}$.

On the basis of the design research using the MineScape program for the prospective zinc and lead ore deposit in the Olkusz region in Poland, this study concluded that

- The minimum and maximum depths of ore-bearing dolomites modeled in the MineScape program ranged from 69.1 to $136.8 \mathrm{~m}$;

- Deposit thickness was very variable and ranged from $15 \mathrm{~m}$ to $55 \mathrm{~m}$;

- The maximum length of the strip excavation was $35 \mathrm{~m}$.

The time to fill in was found to be most influenced by height difference of the mixture inlet and outlet of the backfill; equivalent length of the backfilling installation; kineticspecific gravity; and unit energy losses, working velocity, critical velocity, and maximum grain size. Calculated backfilling times did not take into account the time associated with shortening the pipeline as the backfilling was filled. In addition, when calculating the total time needed to eliminate the selected post-mining space, one should also take into account the technological processes related to the flushing time of the backfilling installation, which takes into account the actual length and diameter of the pipeline and the construction of backfilling dams. The presented BackfillCAD model can be useful at the planning and scheduling stage for both operating mining plants and, above all, for new prospective deposits of mineral resources.

Funding: This research was prepared as part of AGH University of Science and Technology in Poland, scientific subsidy under number: 16.16.100.215.

Data Availability Statement: The data presented in this study are new and have not been previously published.

Conflicts of Interest: The author declares no conflict of interest.

\section{References}

1. Huang, Y.; Zhang, J.; Yin, W.; Sun, Q. Analysis of Overlying Strata Movement and Behaviors in Caving and Solid Backfilling Mixed Coal Mining. Energies 2017, 10, 1057. [CrossRef]

2. Feng, J.; Peng, H.; Shuai, G.; Meng, X.; Lixin, L. A roof model and its application in solid backfilling mining. Int. J. Min. Sci. Technol. 2017, 27, 139-143. [CrossRef]

3. Zhang, J.; Li, B.; Zhou, N.; Zhang, Q. Application of solid backfilling to reduce hard-roof caving and longwall coal face burst potential. Int. J. Rock Mech. Min. Sci. 2016, 88, 197-205. [CrossRef]

4. Wang, L.; Chen, G.; Chen, S. Experimental study on seismic response of geogrid reinforced rigid retaining walls with saturated backfill sand. Geotext. Geomembr. 2015, 43, 35-45. [CrossRef]

5. Bai, E.; Guo, W.; Tan, Y.; Yang, D. The analysis and application of granular backfill material to reduce surface subsidence in China's northwest coal mining area. PLoS ONE 2018, 13, e0201112. [CrossRef] 
6. Wang, F.; Ma, Q.; Li, G.; Wu, C.; Guo, G. Overlying Strata Movement Laws Induced by Longwall Mining of Deep Buried Coal Seam with Superhigh-Water Material Backfilling Technology. Adv. Civ. Eng. 2018, 2018, 1-10. [CrossRef]

7. Lingga, B.A.; Apel, D.B. Shear properties of cemented rockfills. J. Rock Mech. Geotech. Eng. 2018, 10, 635-644. [CrossRef]

8. Sivakugan, N.; Rankine, R.M.; Rankine, K.J.; Rankine, K.S. Geotechnical considerations in mine backfilling in Australia. J. Clean. Prod. 2006, 14, 1168-1175. [CrossRef]

9. Li, J.; Yin, Z.Q.; Li, C.M. Waste rock filling in fully mechanized coal mining for goaf-side entry retaining in thin coal seam. Arab. J. Geosci. 2019, 12, 509. [CrossRef]

10. Nujaim, M.; Belem, T.; Giraud, A. Experimental Tests on a Small-Scale Model of a Mine Stope to Study the Behavior of Waste Rock Barricades during Backfilling. Minerals 2020, 10, 941. [CrossRef]

11. Zhou, N.; Du, E.; Zhang, J.; Zhu, C.; Zhou, H. Mechanical properties improvement of Sand-Based cemented backfill body by adding glass fibers of different lengths and ratios. Constr Build Mater. 2021, 280, 122408. [CrossRef]

12. Hefni, M.; Hassani, F. Experimantal development of a novel mine backfill material: Foam mine fill. Minerals 2020, 10, 564. [CrossRef]

13. Chen, S.; Yin, D.; Cao, F.; Liu, Y.; Ren, K. An overview of integrated surface subsidence-reducing technology in mining areas of China. Nat Hazards 2016, 81, 1129-1145. [CrossRef]

14. Huang, P.; Zhang, J.; Yan, X.; Spearing, A.J.S.; Li, M.; Liu, S. Deformation response of roof in solid backfilling coal mining based on viscoelastic properties of waste gangue. Int. J. Min. Sci. Technol. 2021, 31, 279-289. [CrossRef]

15. Zhang, J.; Zhang, Q.; Spearing, A.J.S.; Miao, X.; Guo, S.; Sun, Q. Green coal mining technique integrating mining-dressing-gas draining-backfilling-mining. Int. J. Min. Sci. Technol. 2017, 27, 17-27. [CrossRef]

16. Pu, H.; Zhang, J. Research on protecting the safety of buildings by using backfill mining with solid. Procedia Environ. Sci. 2012, 12, 191-198. [CrossRef]

17. Huang, P.; Spearing, S.; Ju, F.; Jessu, K.V.; Wang, Z.; Ning, P. Control Effects of Five Common Solid Waste Backfilling Materials on In Situ Strata of Gob. Energies 2019, 12, 154. [CrossRef]

18. Mo, S.; Canbulat, I.; Zhang, C.; Oh, J.; Shen, B.; Hagan, P. Numerical investigation into the effect of backfilling on coal pillar strength in highwall mining. Int. J. Min. Sci. Technol. 2018, 28, 281-286. [CrossRef]

19. Skrzypkowski, K. Decreasing Mining Losses for the Room and Pillar Method by Replacing the Inter-Room Pillars by the Construction of Wooden Cribs Filled with Waste Rocks. Energies 2020, 13, 3564. [CrossRef]

20. Deng, X.J.; Zhang, J.X.; Zhou, N.; Wit, B.; Wang, C.T. Upward slicing longwall-roadway cemented backfilling technology for mining an extra-thick coal seam located under aquifers: A case study. Environ. Earth Sci. 2017, 76, 789. [CrossRef]

21. $\mathrm{Wu}, \mathrm{J}$. Research on sublevel open stoping recovery processes of inclined medium thick orebody on the basis of physical simulation experiments. PLoS ONE 2020, 15, e0232640. [CrossRef]

22. Zhou, N.; Yan, H.; Jiang, S.; Sun, Q.; Ouyang, S. Stability Analysis of Surrounding Rock in Paste Backfill Recovery of Residual Room Pillars. Sustainability 2019, 11, 478. [CrossRef]

23. Wang, F.; Jiang, B.; Chen, S.; Ren, M. Surface collapse control under thick unconsolidated layers by backfilling strip mining in coal mines. Int. J. Rock Mech. Min. Sci. 2019, 113, 268-277. [CrossRef]

24. Lu, B.; Li, Y.; Fang, S.; Lin, H.; Zhu, Y. Cemented Backfilling Mining Technology for Gently Inclined Coal Seams Using a Continuous Mining and Continuous Backfilling Method. Shock. Vib. 2021, 2021, 1-12. [CrossRef]

25. Qiang, Z.; Jixiong, Z.; Shuai, G.; Rui, G.; Weikang, L. Design and application of solid, dense backfill advanced mining technology with two pre-driving entries. Int. J. Min. Sci. Technol. 2015, 25, 127-132. [CrossRef]

26. Zhao, T.; Zhang, Z.; Yin, Y.; Tan, Y.; Liu, X. Ground control in mining steeply dipping coal seams by backfilling with waste rock. J. S. Afr. Inst. Min. Metall. 2018, 118, 15-26. [CrossRef]

27. Gonen, A.; Kose, H. Stability analysis of open stopes and backfill in longhole stoping method for Asikoy underground copper mine. Arch. Min. Sci. 2011, 56, 375-387.

28. Raffaldi, M.J.; Seymour, J.B.; Richardson, J.; Zahl, E.; Board, E. Cemented Paste Backfill Geomechanics at a Narrow-Vein Underhand Cut-and-Fill Mine. Rock. Mech. Rock. Eng. 2019, 52, 4925-4940. [CrossRef]

29. Dzimunya, N.; Radhe, K.; Chanda, M.; William, C.M. Design and dimensioning of sublevel stoping for extraction of thin ore ( $<12$ $\mathrm{m}$ ) at very deep level: A case study of konkola copper mines (kcm), Zambia. Math. Model. Eng. Probl. 2018, 5, 27-32. [CrossRef]

30. Zhang, Q.L.; Hu, G.Y.; Wang, X.M. Hydraulic calculation of gravity transportation pipeline system for backfill slurry. J. Cent. South Univ. Technol. 2008, 15, 645-649. [CrossRef]

31. Sivakugan, N.; Veenstra, R.; Naguleswaran, N. Underground Mine Backfilling in Australia Using Paste Fills and Hydraulic Fills. Int. J. Geosynth. Ground Eng. 2015, 1, 1-18. [CrossRef]

32. Polish Committee for Standardization. Polish Standard: PN-G-11010; Mining-Materials for hydraulic backfill-Requirements and tests; Polish Committee for Standardization: Warszawa, Poland, 1993. (In Polish)

33. Piechota, S. Technika Podziemnej Eksploatacji złóż i Likwidacji Kopalń (Technique of Underground Mining Deposits and Liquidation of Mines); AGH Publishing House: Kraków, Poland, 2008; pp. 252-256. (In Polish)

34. Laser Particle Sizer ANALYSETTE 22 MicroTec Plus. Available online: https://www.ulprospector.com/en/asia/Coatings/ Detail/6647 / 204545/Laser-Particle-Sizer-ANALYSETTE-22-MicroTec-Plus (accessed on 17 May 2021).

35. MineScape. Available online: https://www.dataminesoftware.com/solutions/minescape-geological-modelling-mine-planning (accessed on 18 May 2021). 
36. Skrzypkowski, K. The Influence of Room and Pillar Method Geometry on the Deposit Utilization Rate and Rock Bolt Load. Energies 2019, 12, 4770. [CrossRef]

37. Polish Geological Institute, National Research Institute. Available online: https://www.pgi.gov.pl/oferta-inst/wydawnictwa/ serie-wydawnicze/bilans-zasobow-kopalin.html (accessed on 18 May 2021).

38. Geological Documentation of the Olkusz-Pomorzany Mine; Mining and Metallurgy Plant: Bukowno, Poland, 2020. (In Polish)

39. Kowalski, A. Surface Deformation in the Upper Silesian Coal Basin; Central Mining Institute Publisher: Katowice, Poland, 2015; p. 105. (In Polish) 